Article

\title{
Fixed Narratives and Entangled Categorizations: Educational Problematizations in Times of Politicized and Stratified Migration
}

\author{
Kenneth Horvath \\ Department of Sociology, University of Lucerne, 6002 Lucerne, Switzerland; E-Mail: kenneth.horvath@unilu.ch
}

Submitted: 8 April 2018 | Accepted: 21 June 2018 | Published: 30 August 2018

\begin{abstract}
Western European migration and citizenship regimes have undergone profound transformations over the past decades. The massive politicization and stratification of migration are key features of these dynamics. Focusing on the case of Germany, this article investigates how these developments affect logics of educational practice. It is argued that teachers, faced with increasingly complex and uncertain situations, systematically draw on categories that combine political and educational logics. These "entangled categories" do hardly allow to unravel the complex configurations currently at stake at the intersection of migration and education. A secondary analysis of TIMSS-2015 data is performed to substantiate the article's core hypothesis: these forms of categorization have crystallized into patterns of educational problematization that couple perceptions of educational challenges, professional self-images, and didactic approaches. These fixed narratives disproportionally affect migrant children from underprivileged social backgrounds. They hence have important implications both for our understanding of educational inequalities in times of politicized and stratified migration and for furthering professional reflexivity.
\end{abstract}

\section{Keywords}

differentiated citizenship; educational classification; educational problematization; migration regimes; politicization of migration; TIMSS-2015

\section{Issue}

This article is part of the issue "Migration, Boundaries and Differentiated Citizenship", edited by Terry Wotherspoon (University of Saskatchewan, Canada).

(C) 2018 by the author; licensee Cogitatio (Lisbon, Portugal). This article is licensed under a Creative Commons Attribution 4.0 International License (CC BY).

\section{Introduction}

Migration is among the most salient political issues of our time. Especially in Western Europe, the politicization of migration (Hammar, 2007) has gone hand in hand with the stratification of civic, political, and social rights (Amelina, Horvath, \& Meeus, 2016; Engbersen, Leerkes, Scholten, \& Snel, 2017). Citizenship regimes and orders of belonging have become differentiated along lines such as profession, qualification, ethnic belonging, region of origin, language skills, or even age. It seems natural to ask how the field of education is affected by these processes. After all, education systems are among the first societal institutions that need to react to changing social and political structures. More importantly, educational practices matter; they are crucial for the distributions of life opportunities as well as for the formation of political and cultural identities.
Against this background, this article discusses how forms of educational classification and problematization are affected by current political dynamics. Focusing on the case of Germany, it develops and substantiates the hypothesis that fixed patterns of educational problematization have emerged. These narratives are linked to categories that are best described as entangled: while deeply marked by political and public discourses, their everyday usage by teachers is anchored in the structures of educational practice. These potentially detrimental forms of categorization and problematization disproportionally affect migrant students from disadvantaged socioeconomic backgrounds.

The presented findings promise to further our understanding of how educational inequalities are reproduced in times of politicized and stratified migration, without presupposing ill intentions by teachers or any other oversimplified linkage of politics and education. 
Section 2 presents the theoretical framework that motivates and informs the analysis and discusses relevant developments of Western European migration regimes. Linking these discussions to findings from qualitative interview studies, the concepts of entangled categorization and fixed narratives are introduced. Sections 3 and 4 present the methodological foundations of and findings from a secondary analysis of TIMSS 2015 data. Multiple Correspondence Analysis is used to explore how perceptions of educational challenges, professional selfimages, and didactic strategies are related to each other as well as to students' background variables. The presented findings have important implications for professional reflexivity and for our understanding of educational inequalities.

\section{The Politics of Migration, Educational Classification, and the Emergence of Fixed Narratives}

\subsection{Linking Migration, Politics, and Education}

Studies based on large scale assessments such as PISA have painted a detailed picture of educational disadvantages of migrant and minority children (Borgna, 2017; Dronkers, van der Velden, \& Dunne, 2012; Gracia, Vázquez-Quesada, \& van de Werfhorst, 2016; Volante, Klinger, \& Bilgili, 2018). Existing analyses have, however, paid little attention to the relevance of migration and citizenship regimes for these inequalities. Among the few exceptions are Hochschild and Cropper (2010) who offer a comparative exploration of links between immigration and schooling regimes, Entorf and Minoiu (2005) who analyze the effect of immigration regimes on educational attainment and van der Werfhorst and Heath (2018) who investigate correlations between selectivity of immigration regimes and educational disadvantages. These studies illustrate how complex the interplay between migrant biographies, educational institutions, and migration and citizenship regimes is. Our overall picture of these relations is still sketchy and the mechanisms that link political and educational dynamics remain unclear.

Scholars in the fields of critical pedagogy and multicultural education likewise discuss the interplay of migration, inequalities, politics, and education, but from a somewhat different perspective. Relating empirical studies to normative theory, they call for raising awareness of the social and political embedding of educational practice in order to further equality and empowerment (Agirdag, Merry, \& van Houtte, 2016; Alismail, 2016; Kolano, Dávila, Lachance, \& Coffey, 2013). Formations of "race" and ethnicity stand center stage in these research contexts. That also holds true for the German speaking world where social sciences are otherwise very hesitant to refer to notions of "race" or racism. Against this background, scholars from the field of critical and anti-racist pedagogy have made an important impact by investigating processes of ethnicized subjectification, by criticizing essentialist understandings, and by pointing out how deeply educational practices are embedded in postcolonial orders of domination and inequality (Broden \& Mecheril, 2010; Mecheril, 2018; Terkessidis, 2016; Wischmann, 2018). These studies clarify the political character and underpinnings of educational practices and discourses. The political itself, however, is treated in rather general and abstract terms. The present article is motivated by the conviction that a more concrete understanding of the links between politics and education is helpful for critically engaging with how teachers make sense of the everyday challenges they are facing.

This article builds on and adds to these existing studies in two ways. It first aims to further our understanding of a key mechanism for the reproduction and transformation of educational inequalities. Second, it wants to contribute to debates in multicultural education and anti-racist pedagogy by adding an empirically grounded hypothesis concerning the concrete ways in which historically situated political dynamics become effective in everyday educational practice. The main implication of the discussion is that in addition to prepare "teachers for classrooms that reflect racially, culturally, and linguistically diverse student populations" (Kolano et al., 2013 , p. 42, emphasis added), there is also an increasing need to raise awareness of legal, political, and social stratification-and for the categories that are used to capture these complexities in a highly politicized context. In other words, the article takes the challenge seriously to identify the educational implications of the "growing significance of racial and ethnic representation in post-World War II western society" (Wotherspoon \& Jungbluth, 1995, p. 4) and, on this basis, to reconsider the role of the political in pedagogical everyday life.

\subsection{Politicization, Boundary Making, and Stratification: Core Aspects of Current Political Dynamics}

With these objectives in view, three related political developments deserve attention. The first is the massive politicization of migration over the past decades (Hammar, 2007; van der Brug, D’Amato, Ruedin, \& Berkhout, 2015). Of course, migration has been a contested issue and the matter of intense public debate before; after all, it touches on fundamental tensions inherent to the political form of the liberal nation-state (Hollifield, 2004). But the degree, the quality, and the social significance of the current politicization of migration must be considered exceptional, especially in the European context. From the early 1990s onwards, migration has been among the core issues of almost every political election in European representative democracies (Lefkofridi \& Horvath, 2012). This political salience is coupled to the rise of new right-wing parties, a development that has affected party systems to the East and to the West of the former Iron Curtain (Muis \& Immerzeel, 2017). This exceptional politicization can be traced back to post-World War II labour migration systems, but massively gained momentum following the end of the Cold War (Horvath, 
2014a). It since seems to have stabilized due to an interplay of geopolitical, economic, social, and cultural developments (Amelina et al., 2016). Mirroring the contradictory social processes underlying them, current debates on migration and citizenship are further marked by divergent (even if related) forms of problematization: on the one hand, migration is heavily securitized and discussed as threat to national identity, public order, and social security (Huysmans, 2000); on the other hand, it is framed as a necessity of our globalized and cosmopolitan age, a factor rationally to be included in political-economic costbenefit calculations (Horvath, 2014b).

This ambivalent and tension-filled politicization is, second, linked to the (re-)making of boundaries, borders, and orders of belonging (Wimmer, 2013). Hard and physical consequences of militarized re-bordering processes at the "edges" of Europe (De Genova, 2017; Walters, 2016) go hand in hand with the differentiation of orders of belonging and identity "in the middle" of European political spaces and discourses (Balibar, 2009; Pries, 2013; Ryan, 2018). Against this background, new forms of social classification have emerged. These classifications less than ever take the form of clear-cut and welldefined taxonomies. Rather they amount to vague and ambiguous notions such as "migration background" or the "(Arab) refugee" (Horvath, 2017, 2018).

Third, the two discursive processes of politicization and boundary making have been paralleled by a considerable stratification of civic, political, and social rights. Well-secured social, mobility, and settlement rights for some stand in sharp contrast to the enforced temporariness and the deprivation of fundamental rights for others (Balibar, 2009; Mezzadra \& Neilson, 2013). This stratification of migration and citizenship is part of ongoing political-economic transformation processes that simultaneously entail increasing transnational flows of goods, capital, and manpower and the immobilization of substantial parts of the world population (De Giorgi, 2010). From a diachronic angle, the stratification of migration and citizenship also mirrors the overlap of migration systems that have emerged at different points in time, including the post-guestwork formation of new ethnic minorities, intra-EU labour force mobility, international student mobility, corporate migration, and recent refugee movements (Engbersen et al., 2017; Horvath, Amelina, \& Peters, 2017).

\subsection{Entangled Classifications and Fixed Narratives: How Political Dynamics Influence Educational Logics}

How are logics of educational practice affected by these developments? This section re-reads findings from qualitative interview studies (Horvath, 2017, 2018, In Press) in the light of the discussed political developments. ${ }^{1}$ The argument is presented in the condensed form of conjec- tures that introduce the concepts of entangled classification and fixed narratives and prepare the ground for the statistical analysis in Section 4.

The neo-pragmatist heuristics that guide the following discussion draw on the "sociology of conventions" and strands of science and technology studies (Boltanski \& Thévenot, 2006; Diaz-Bone, 2011). Teachers are conceived of as competent actors faced with the permanent need to define and handle uncertain situations in a professional (generalizable and justifiable) manner (Derouet, 1992; Imdorf, 2011; Leemann, 2014). In order to do so, they rely on different forms of conventionalized cognitive resources, including orders of justification and, crucial for this article, systems of social classification (Boltanski \& Thévenot, 1983). These cognitive resources may be read as elements of a "knowledge infrastructure" (Bowker \& Star, 1999): they are made in the sense of being the historical product of earlier social agency, they are always embedded in wider institutions and structures, they have a certain reach and scope across fields of practice, and they provide ready-made forms and formats that can be used for different purposes. Categories that are part of this kind of societal knowledge infrastructure will often be akin to what Rosch (1983) has famously characterized as "prototype classification": categories that are only implicitly and vaguely defined and combine heterogeneous elements with varying priorities (to illustrate the idea, Rosch has for example shown how some pieces of furniture are perceived as more typical for the category of furniture than others, just as some breeds of dogs are granted a higher degree of "dog-ness" than others).

A first and important implication of this framework is that we cannot presuppose any simple translation of political dynamics into educational logics. Teachers are seen as being first and foremost oriented towards following professional standards and demands (Derouet, 1992). In line with this assumption, there are no indications in the interviews that teachers consciously apply different logics of evaluation to migrant or minority students than to native pupils. Neither is there a one-to-one reproduction of public discourses. For example, when teachers speak of "integration", they overwhelmingly use the term to describe group constellations and dynamics, in sharp contrast to currently dominant political notions of integration that emphasize matters of identity and belonging (Korteweg, 2017).

Based on the presented heuristics, it seems nonetheless reasonable to assume that political developments leave their traces in the educational field. First, migration and citizenship regimes might influence the actual situations teachers need to define and handle. Second, they may affect the set of cognitive resources that teachers rely on. On this basis, three interrelated conjectures can be derived:

\footnotetext{
${ }^{1}$ For methodological details and findings of these studies see Horvath (2017, 2018; In Press). The first of the studies investigated educational patterns of classification. In extensive interviews, preschool and primary school teachers were asked to characterize their institution, their class, and each of their pupils. The second study explored how teachers explain educational inequalities and the categories they mobilize to do so.
} 
The first conjecture is that the stratification and politicization of migration have made educational situations more uncertain. Migration biographies and statuses have become increasingly diverse. In the 1980 s, the rough distinction of native and foreign citizenship sufficed in German speaking countries to delimit and denote "guestworker children" as "problematic" part of the student population. Nowadays, social backgrounds and migration statuses are far less strongly coupled. This diversification of migration-related statuses is obvious in teachers' characterizations of their students. Children from families with a migration biography are to be found among students described as economically privileged and those seen as disadvantaged, students with welleducated and career-oriented parents as well as those whose parents are perceived as equipped with little cultural capital, among groups of problematic and of complacent students. The integration of migration aspects into pedagogic strategies is hence even less straightforward than during the post-guestwork period. The politicization of migration adds to the resulting uncertainty by rendering migration issues more sensitive. Many interviewed teachers seem aware of the normative tensions involved. For instance, they hesitate to mention migration-related aspects at all, or ask for re-assurance from the interviewer whether "that belongs here". A pattern emerges that seems incoherent on first inspection. In some cases, migration aspects are, if at all, mentioned in a casual and implicit manner, with no mention of any pedagogical relevance; a student's father might "originally be from Japan", another student may "speak French at home", but little seems to follow from these observations. In other cases, mentions of a migration background take the form of outright diagnoses that figure prominently in pedagogic problem definitions.

The second conjecture is that teachers draw on "entangled categories" that carry the marks of politicized boundary making in order to define and handle these increasingly uncertain situations. In order to cope with ambiguous and charged situations, teachers tend to rely on categories such as "migration background" that follow the logic of prototype classification. The politicization of migration forms the basis on which this kind of classification becomes feasible: it provides the knowledge infrastructure that makes "migration background" available as a common-sense category that seems selfevidently relevant and acceptable. The category's educational semantics diverge from legal and statistical definitions and systematically confound three meaning dimensions (Horvath, 2017): socio-economic status, ethnic belonging, and actually migration-related aspects (such as traumatizing experiences). "Migration background", in other words, is an example for a form of category that figures prominently in teachers' accounts and that can best be described as "entangled": these categories are clearly informed by extra-pedagogic discourses, but their usage by teachers is anchored in the demands and structures of educational practice (Horvath, 2018).
Perhaps paradoxically, the very vagueness of these "entangled categories" may help dealing with increasing insecurity-among others by providing discursive shorthands that may structure overarching narratives of educational problematization.

A third conjecture is that, around these entangled categories, fixed narratives have emerged that relate educational problem understandings, professional selfconcepts, and everyday pedagogic strategies. A neopragmatist perspective suggests investigating how categories and classifications are used for defining and handling situations. "Entangled categories" are not necessarily problematic-but become consequential when used for the definition and handling of situations. In the interviews, how strongly teachers emphasize the entangled category of "migration background" is clearly correlated with the degree and form of problematization. While pervasive in cases presented as challenging, they hardly ever play a relevant role in narratives of educational success. Fixed narratives seem to have emerged on this basis. A prominent example is the narrative of "Brennpunktschule" (literally "school in a social focal point"): a brief remark that "90 percent of students have a migration background" suffices in the eyes of the teachers to evoke this narrative that systematically combines perceptions of challenges, assessments of students (and parents), and strategies that seem feasible and acceptable to deal with the situation. The notion of "migration background" functions as a kind of shortcut for this narrative, with potentially far-reaching consequences. For example, based on this overarching narrative, teachers routinely refer to presumably difficult family backgrounds as explanations for educational problems-thereby simultaneously defining the problem as beyond their own pedagogical control.

To sum up, teachers draw on a wider societal knowledge infrastructure that is marked by the politicization of migration, thus introducing entangled categories into their narratives of educational problematization. These narratives aim at defining and handling educational situations that have become more complex and uncertain following the stratification of migration. Although the narratives themselves may well correspond to professional logics, they are presumably problematic because they mirror relations of dominance and inequality. They might have important consequences because they affect how situations and pupils are defined as problematic and inform the concrete pedagogic and didactic strategies that seem feasible and acceptable for dealing with them. But do these qualitative findings translate into regularities on a larger scale? If so, should we assume that these patterns are systematically related to students' social backgrounds?

\section{Methodological Remarks}

Section 4 provides a first quantitative answer to these questions on the basis of a secondary analysis of TIMSS 
2015 data. The Trends in Mathematics and Science Study is an international large scale assessment study that is carried out by the International Association for the Evaluation of Educational Achievement (IEA) every four years. Its main objective is to monitor mathematical and science competences of school students in comparative perspective. These competence assessments are complemented by comprehensive contextual data collections for students, parents, teachers, and schools. The following analysis focuses on Germany, but brief references are made to other Western European countries as well as to Canada and Australia. The aim is to explore patterns in teachers' problematizations and how they are linked to students' social and migration backgrounds. To this end, variables from the teacher survey were linked to information from student and home questionnaires. The German dataset comprises data on 307 teachers and 3,948 pupils.

Multiple correspondence analysis (MCA) is used to construe an educational "problematization space" using these data (Le Roux \& Rouanet, 2010; Mundt \& Horvath, In Press). MCA is a statistical procedure that works with categorical data and is therefore particularly apt for social science applications (Greenacre \& Blasius, 2006). It is an exploratory statistical technique that aims at identifying complex relations in data and displaying them geometrically. The analytical aim is not to quantify isolated effects of predefined independent variables on a dependent variable, but rather to explore relations between (categories of) variables and individuals in their complexity and multiplicity.

The interpretation of MCA findings usually concentrates on the graphical result. In a nutshell, MCA represents similarities between cases or correlations between variables topologically in a map: the more similar cases and the stronger correlated categories of variables, the closer to each other they are displayed. To talk of educational "spaces of problematization" or "knowledge spaces" in MCA contexts thus simply means that aspects of teachers' overall problematizations that tend to cooccur are displayed close to each other. The axes of an MCA map are considered to mirror underlying structures. The interpretation therefore entails two related steps. (1) The axes are interpreted by looking at how categories of variables are distributed along them. The relative importance of an axis is expressed numerically as its share of "total inertia" (basically the proportion of total variation explained by the axis). (2) Points are interpreted by looking at their positions relative to each other. Some points can be more important for the overall solution than others - these points have a high "weight" and a stronger influence on the overall shape of the map. Variables that are used to define the MCA space are referred to as "active variables". The projection of "passive variables" (which do not affect the shape of the space) into a given map allows to relate the identified patterns to other factors.

A caveat is in order. TIMSS data are produced on the basis of conceptual frameworks that are quite different from the one of this article. The TIMSS teacher survey covers a range of significant indicators for teachers' problem perceptions but does not include items that can be interpreted as measuring underlying logics of classification. Conclusions from patterns of problematization to "entangled categories" are therefore made by adding migration background as a passive variable. Further, the set of available migration-related variables is restricted. The father's country of birth is used as an indicator in the following - this only allows a rough approximation of the population of students "with a migration background". Overall, the data and findings are nonetheless meaningful and suggestive for the exploratory ends of this article.

\section{A Firmly Fixed Pattern?}

In the following, data from TIMSS 2015 on teachers' perceptions of their school and their students, on their professional self-images, and on their didactic strategies are used to construe a "space of educational problematization". The included items are listed in Table 1. The leading question is whether "problematic problematizations" as they have been postulated in Section 2.3 can be identified on a larger scale. In a second step, student background variables are projected into this space of problematization to give a first indication of how the observed patterns may be linked to underlying categories and to explore how teachers' "knowledge spaces" are related to students' social spaces. The country of birth and the educational qualification of students' fathers are used in this article, but other variables (parents' employment status, overall social structure of the school etc.) lead to similar results. Third, the combined findings are discussed in the light of the considerations presented in Section 2.

Figure 1 shows the MCA map for the selected items. A surprisingly clear pattern arises that is in line with the diagnosis of fixed narratives. From left to right, teachers' perceptions and assessments become increasingly negative for all investigated aspects: students' behaviour and capabilities, parents' support, and the school's sociospatial context are positively evaluated on the left-hand side and seen negatively on the right-hand side. Teachers' didactic strategies follow the same pattern. On the right-hand side of the map, teachers report that they seldom encourage classroom discussions or provide students with challenging tasks, in sharp contrast to teaching habits on the other side of the map. The same pattern, finally, is obvious for how teachers' emotionally relate to their professional role and for their job satisfaction: the further to the right, the less satisfied and enthusiastic teachers are, and the less they find their work full of meaning and purpose. There is no systematic pattern on the $y$-axis, suggesting a one-dimensional solution. $21.5 \%$ of total inertia is explained, which indicates a normal to good representation of overall variety.

Taking a more detailed look at single points and their interrelations, the homologies to the narratives of 
Table 1. Items used for MCA.

\begin{tabular}{|c|c|c|c|c|}
\hline Item & & Univariate $\mathrm{d}$ & tribution & \\
\hline $\begin{array}{l}\text { How would you characterize each of the following within } \\
\text { your school? }\end{array}$ & Very high & High & Medium & (Very) Low \\
\hline - Parental expectations for student achievement & $4.4 \%$ & $24.4 \%$ & $49.6 \%$ & $21.5 \%$ \\
\hline - Parental support for student achievement & $11.4 \%$ & $54.0 \%$ & $31.6 \%$ & $2.9 \%$ \\
\hline - Students' ability to reach school's academic goals & $2.2 \%$ & $18.5 \%$ & $59.8 \%$ & $19.5 \%$ \\
\hline $\begin{array}{l}\text { Thinking about your current school, indicate the extent to which } \\
\text { you agree or disagree with each of the following statements. }\end{array}$ & $\begin{array}{l}\text { Agree } \\
\text { a lot }\end{array}$ & $\begin{array}{l}\text { Agree } \\
\text { a little }\end{array}$ & $\begin{array}{l}\text { Disagree } \\
\text { a little }\end{array}$ & $\begin{array}{l}\text { Disagree } \\
\quad \text { a lot }\end{array}$ \\
\hline - This school is located in a safe neighborhood & $61.3 \%$ & $29.2 \%$ & $7.3 \%$ & $2.2 \%$ \\
\hline - The students behave in an orderly manner & $21.2 \%$ & $63.4 \%$ & $13.6 \%$ & $1.8 \%$ \\
\hline - The students are respectful of the teachers & $21.6 \%$ & $65.9 \%$ & $12.1 \%$ & $0.4 \%$ \\
\hline $\begin{array}{l}\text { How often do you feel the following way about being } \\
\text { a teacher? }\end{array}$ & Very often & Often & Sometimes & $\begin{array}{c}\text { (Almost) } \\
\text { never }\end{array}$ \\
\hline - I am content with my profession as a teacher & $43.8 \%$ & $50.7 \%$ & $5.1 \%$ & $0.4 \%$ \\
\hline - I find my work full of meaning and purpose & $61.8 \%$ & $36.0 \%$ & $1.8 \%$ & $0.4 \%$ \\
\hline - I am enthusiastic about my job & $44.7 \%$ & $42.5 \%$ & $12.1 \%$ & $0.7 \%$ \\
\hline How often do you do the following in teaching this class? & $\begin{array}{l}\text { (Almost) } \\
\text { every lesson }\end{array}$ & $\begin{array}{l}\text { About half } \\
\text { the lessons }\end{array}$ & $\begin{array}{l}\text { Some } \\
\text { lessons }\end{array}$ & Never \\
\hline - Relate the lesson to students' daily lives & $47.1 \%$ & $39.0 \%$ & $14.0 \%$ & $0.0 \%$ \\
\hline $\begin{array}{l}\text { - Complete challenging exercises that require to go } \\
\text { beyond the instruction }\end{array}$ & $7.6 \%$ & $28.7 \%$ & $60.4 \%$ & $3.3 \%$ \\
\hline - Encourage classroom discussions among students & $19.0 \%$ & $39.1 \%$ & $40.5 \%$ & $1.5 \%$ \\
\hline $\begin{array}{l}\text { - Ask students to decide their own problem } \\
\text { solving procedures }\end{array}$ & $26.6 \%$ & $49.6 \%$ & $23.7 \%$ & $0.0 \%$ \\
\hline $\begin{array}{l}\text { In your view, to what extent do the following limit how you } \\
\text { teach this class? }\end{array}$ & Not at all & Some & A lot & \\
\hline - Students lacking prerequisite knowledge or skills & $10.7 \%$ & $63.1 \%$ & $26.2 \%$ & \\
\hline — Disruptive students & $20.6 \%$ & $58.5 \%$ & $21.1 \%$ & \\
\hline - Uninterested students & $26.9 \%$ & $65.1 \%$ & $8.0 \%$ & \\
\hline
\end{tabular}

Notes: Item phrasings in this table are taken from the English reference questionnaires (which was translated and adapted for each participating country); $\mathrm{N}=307$; rounding errors possible.

migration-related problematics found in the qualitative studies becomes even stronger. The upper right-hand side of the map seems to be an ideal-typical representation of the narrative of "Brennpunktschule" (see Section 2.3). The map, however, also indicates that there is room for pedagogical manoeuvre. Pronounced perceptions of problems-and this seems very important-on this side of the map are not as strongly correlated with didactic strategies and professional self-images as on the left-hand side (as indicated by the relative distance of the respective points). Sharing a perception of social problems does not mean that teachers deal with these problems the same way.

The projection of passive variables shows that problematization patterns are related to migration issues, but at the same time to issues of social class. Children with foreign-born fathers are over-represented in contexts that teachers perceive as problematic and underrepresented in those considered more beneficial. The same holds true for parents' educational background. Statistically speaking, migrant students (especially those from disadvantaged social backgrounds) are situated in different learning spaces than "native" students. Figure 2 shows the projection of students into teachers' knowledge space. The concentration ellipses (which delimit "typical" cases from points considered outliers) clearly diverge for students with foreign-born fathers.

The correlation of problematization patterns with migration-related backgrounds is most likely underestimated in the statistical results due to the insufficient measurement of migrant and minority status in TIMSS data. A systematic comparison of teachers' assessments of parental attitudes, support etc. with the answering patterns of parents themselves is beyond the scope of this article-but the hypothesis that derives from what has been said so far is that teachers' knowledge spaces tend to homogenize social spaces that are actually becoming increasingly differentiated and variegated. The 


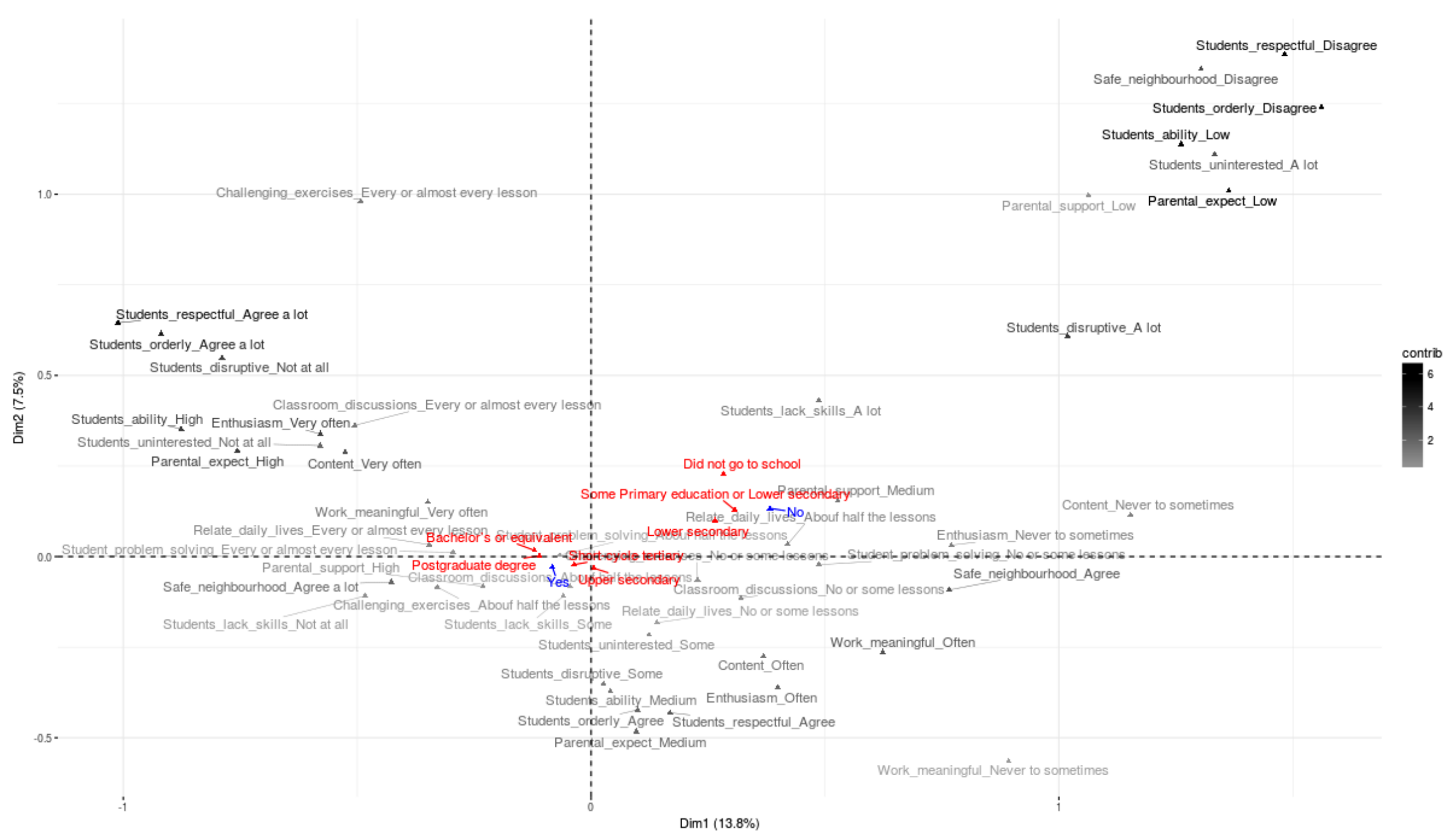

Figure 1. "Educational space of problematization" and background variables. Notes: $21,5 \%$ of total inertia explained; more influential variables coloured darker. Passive variables: blue: father born in Germany (yes/no), red: father's educational level. Categories of some items merged to increase readability and balance skewed distributions. Active Variables taken from teacher questionnaire $(\mathrm{N}=307)$, passive variables taken from the home questionnaire $(\mathrm{N}=3,948)$. 


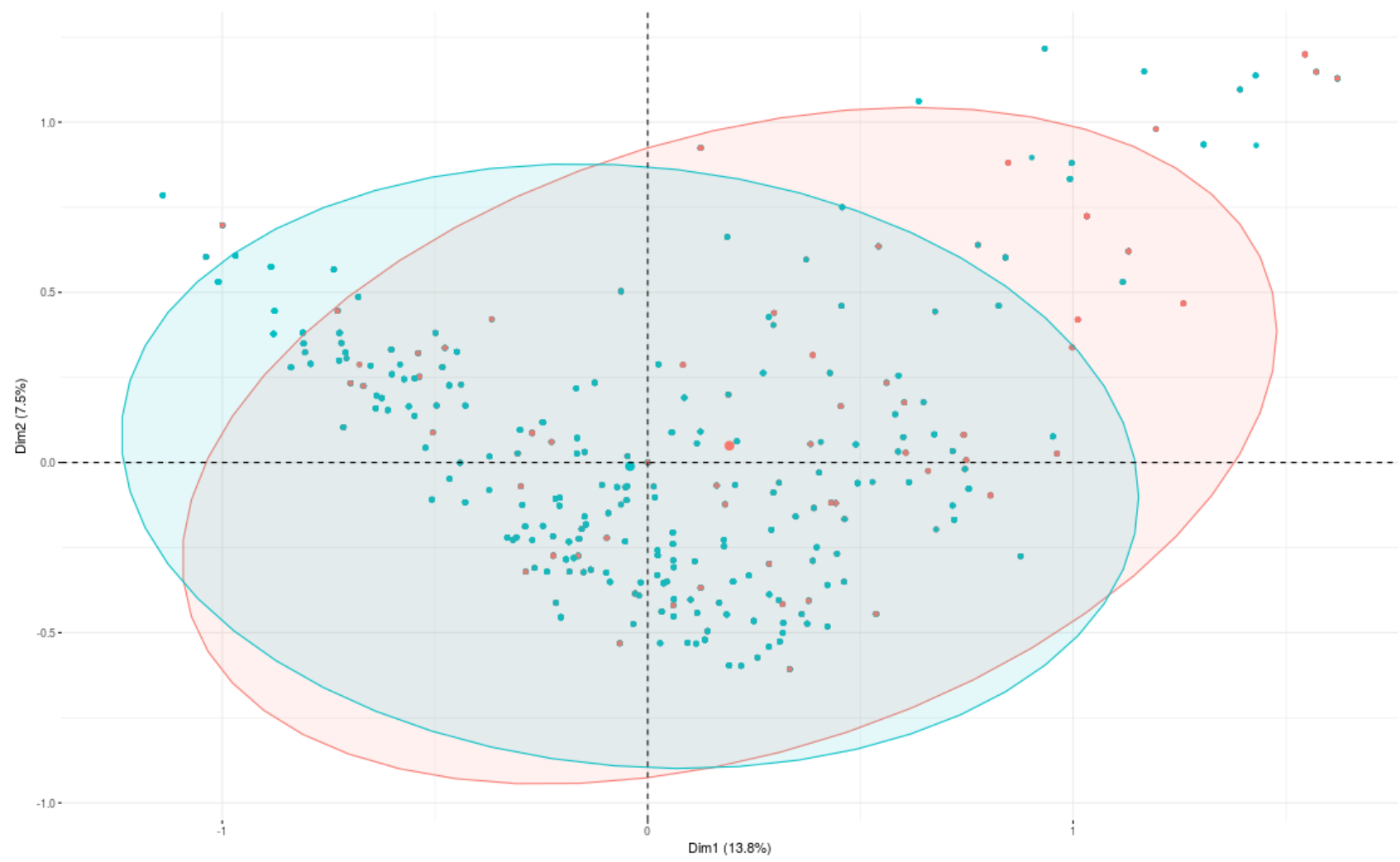

Figure 2. Projections of students into teachers' problematization space. Notes: Points can represent two or several students if these students have the same values on all variables used to construe the MCA space. Red points represent students with foreign-born fathers, cyan points those with fathers born in Germany.

described discursive formation hence threatens to stabilize ethnicized forms of status reproduction in and through schooling systems.

This conjecture needs to be further differentiated. Qualitative findings suggest that the observed narratives are organized around "entangled categories" which help to stabilize them. Not every child with a "migration background" according to legal or statistical definitions is equally likely to be also perceived and labelled as such. The entangled educational category of migration background articulates elements of politicized boundary making with problem definitions of educational practice and therefore systematically conflates socio-economic, ethnicity-related, and migration issues (Horvath, 2017). The concomitant problematization disproportionally affects migrant students from less privileged social backgrounds and accordingly threatens to aggravate inequalities that are already inherent to current stratified migration and citizenship regimes.

MCA maps for other Western European countries lead to similar conclusions, even if the patterns are most pronounced for Germany. In Western Europe, relatively fixed educational narratives seem to have crystallized. Analyses for countries from other world regions yield results that differ in relevant regards. These differences partly mirror variation in migration and citizenship regimes. For example, the space of problematization for Canada becomes two-dimensional, with didactic strate- gies being detached from an otherwise similar first axis; migration and citizenship status seem far less important, in turn there is a stronger association with parents' educational background. For Australia, a similar knowledge space is even reversely linked to migration and citizenship status, in line with the country's highly selective immigration policies: students from migrant families are (slightly) over-represented on the left side of the map, native students on the right.

\section{Conclusion}

This article has discussed the hypothesis that the politicization and stratification of migration and citizenship have given rise to patterns of educational problematization that threaten to aggravate already existing educational disadvantages. Entangled categories that combine pedagogic and political logics presumably play an important mediating and stabilizing role for these fixed narratives. Although focused on the example of Germany, it can be assumed that this diagnosis holds for other Western European countries. After all, the political and social dynamics have been similar across the new European context. First statistical analyses of TIMSS 2015 data seem to warrant this conjecture.

The presented findings offer a starting point to explain the subtle ways in which educational inequalities are reproduced in and through pedagogic practice with- 
out presupposing any automatic process, an unreflecting transfer of political discourses, or even ill intentions by teachers. The mobilization of entangled categories and the fixing of problem narratives is understandable in so far as they allow to deal with the excessive demands and tensions inherent to educational situations. As argued by critical pedagogy and multicultural education, the logical demand and most important remedy is to raise reflexivity and awareness. Extending the scope of professional reflexivity to the political processes discussed in this article may make this critical engagement more effective and sustainable.

The demand for reflexivity extends to the social sciences. Social scientists should be aware of and reflect upon their own role in establishing and fixing societal problematizations and categorizations that might develop unforeseen consequences in various other fields of social practice.

\section{Acknowledgments}

I would like to thank the academic editor and the anonymous reviewers for their helpful comments on an earlier version of this article.

\section{Conflict of Interests}

The author declares no conflict of interests.

\section{References}

Agirdag, O., Merry, M. S., \& van Houtte, M. (2016). Teachers' understanding of multicultural education and the correlates of multicultural content integration in Flanders. Education and Urban Society, 48(6), 556-582.

Alismail, A. H. (2016). Multicultural education: Teachers' perception and preparation. Journal of Education and Practice, 7(11), 139-146.

Amelina, A., Horvath, K., \& Meeus, B. (2016). Migration and social transformation: Interdisciplinary insights and European perspectives. In A. Amelina, K. Horvath, \& B. Meeus (Eds.), An anthology of migration and social transformation. European perspectives (pp. 1-13). Berlin: Springer.

Balibar, E. (2009). We, the people of Europe. Reflections on transnational citizenship. Princeton, NJ: Princeton University Press.

Boltanski, L., \& Thévenot, L. (1983). Finding one's way in social space: A study based on games. Social Science Information, 22(4/5), 631-680.

Boltanski, L., \& Thévenot, L. (2006). On justification. Economies of worth. Princeton, NJ: Princeton University Press.

Borgna, C. (2017). Migrant penalties in educational achievement: Second generation immigrants in Western Europe. Amsterdam: Amsterdam University Press.
Bowker, G. C., \& Star, S. L. (1999). Sorting things out: Classification and its consequences. Cambridge, MA: MIT-Press.

Broden, A., \& Mecheril, P. (Eds.). (2010). Rassismus bildet. Bildungswissenschaftliche Beiträge zu Normalisierung und Subjektivierung in der Migrationsgesellschaft. Bielefeld: transcript.

De Genova, N. (Ed.). (2017). The borders of 'Europe'. Autonomy of migration, tactics of bordering. Durham: Duke University Press.

De Giorgi, A. (2010). Immigration control, post-Fordism, and less eligibility: A materialist critique of the criminalization of immigration across Europe. Punishment \& Society, 12(2), 147-167.

Derouet, J. L. (1992). Ecole et justice-De l'égalité des chances aux compromis locaux? Paris: Métailié.

Diaz-Bone, R. (2011). The methodological standpoint of the 'économie des conventions'. Historical Social Research, 36(4), 43-63.

Dronkers, J., van der Velden, R., \& Dunne, A. (2012). Why are migrant students better off in certain types of educational systems or schools than in others? European Educational Research Journal, 11(1), 11-44.

Engbersen, G., Leerkes, A., Scholten, P., \& Snel, E. (2017). The intra-EU mobility regime: Differentiation, stratification and contradictions. Migration Studies, 5(3), 337-355.

Entorf, H., \& Minoiu, N. (2005). What a difference immigration policy makes: A comparison of PISA scores in Europe and traditional countries of immigration. German Economic Review, 6(3), 355-376.

Gracia, P., Vázquez-Quesada, L. M., \& van de Werfhorst, H. G. (2016). Ethnic penalties? The role of human capital and social origins in labour market outcomes of second-generation Moroccans and Turks in the Netherlands. Journal of Ethnic and Migration Studies, 42(1), 69-87.

Greenacre, M., \& Blasius, J. (Eds.). (2006). Multiple correspondence analysis and related methods. London: Chapman \& Hall.

Hammar, T. (2007). The politicisation of immigration. In T. Abbas \& F. Reeves (Eds.), Immigration and race relations. Sociological theory and John Rex (pp. 99-110). London: I.B. Tauris.

Hollifield, J. (2004). The emerging migration state. International Migration Review, 38(3), 885-912.

Horvath, K. (2014a). Policing the borders of the 'Centaur State': Deportation, detention, and neoliberal transformation processes-The case of Austria. Social Inclusion, 2(3), 113-123.

Horvath, K. (2014b). Securitisation, economisation and the political constitution of temporary migration: The making of the Austrian seasonal workers scheme. Migration Letters, 11(2), 154-170.

Horvath, K. (2017). Migrationshintergrund. Überlegungen zu Vergangenheit und Zukunft einer Differenzkategorie zwischen Statistik, Politik und Pädagogik. In I. Miethe, A. Tervooren, \& N. Ricken (Eds.), Bildung 
und Teilhabe. Zwischen Inklusionsforderung und Exklusionsdrohung (pp. 197-216). Wiesbaden: Springer VS.

Horvath, K. (2018). „Wir können fördern, wir können fordern, aber begaben können wir nicht". Pädagogische Begabungsunterscheidungen im Kontext sozialer Ungleichheiten. In A. Böker \& K. Horvath (Eds.), Begabung und Gesellschaft. Sozialwissenschaftliche Perspektiven auf Begabung und Begabtenförderung (pp. 239-261). Wiesbaden: Springer VS.

Horvath, K. (In Press). Unterschiede, Ungleichheiten, Unterscheidungen. Pädagogisches Kategorisieren zwischen Engagement, Rechtfertigung und Kritik. In P. Gonon, C. Imdorf, \& R. Leemann (Eds.), Bildung und Konventionen. Die ,Économie des conventions' in der Bildungsforschung. Wiesbaden: Springer VS.

Horvath, K., Amelina, A., \& Peters, K. (2017). Re-thinking the politics of migration. On the uses and challenges of regime perspectives for migration research. Migration Studies, 5(3), 301-314.

Hochschild, J. L., \& Cropper, P. (2010). Immigration regimes and schooling regimes: Which countries promote successful immigrant incorporation? Theory and Research in Education, 8(1), 21-61.

Huysmans, J. (2000). The European Union and the securitization of migration. Journal of Common Market Studies, 38(5), 751-777.

Imdorf, C. (2011). Rechtfertigungsordnungen der schulischen Selektion. Wie Schulen die Negativselektion von Migrantenkindern am Übergang in die Sekundarstufe legitimieren. In S. K. Amos, W. Meseth \& M. Proske (Eds.), Öffentliche Erziehung revisited. Erziehung, Politik und Gesellschaft im Diskurs (pp. 225-245). Wiesbaden: Springer VS.

Kolano, L. Q., Dávila, L. T., Lachance, J., \& Coffey, H. (2013). Multicultural teacher education: Why teachers say it matters for preparing them for English language learners. The CATESOL Journal, 26(1), 41-65.

Korteweg, A. (2017). The failures of 'immigrant integration': The gendered racialized production of nonbelonging. Migration Studies, 5(3), 428-444.

Le Roux, B., \& Rouanet, H. (2010). Multiple correspondence analysis. London: Sage.

Leemann, R. (2014). How schools deal with expectations of gender equality. Swiss Journal of Sociology, 40(2), 215-236.

Lefkofridi, Z., \& Horvath, K. (2012). Migration issues and representation in European liberal democracies. Representation, 48(1), 29-46.

Mecheril, P. (2018). Orders of belonging and education: Migration pedagogy as criticism. In D. BachmannMedick \& J. Kugele (Eds.), Migration. Changing concepts, critical approaches (pp. 121-138). Berlin: De Grutyer

Mezzadra, S., \& Neilson, B. (2013). Border as method, or, the multiplication of labor. Durham: Duke University Press.

Muis, J., \& Immerzeel, T. (2017). Causes and consequences of the rise of populist radical right parties and movements in Europe. Current Sociology. La Sociologie Contemporaine, 65(6), 903-930.

Mundt, F., \& Horvath, K. (In Press). Exploring the complex social spaces of higher education. On the uses and challenges of geometric data analysis and topological approaches. In J. Huisman \& M. Tight (Eds.). Theory and method in higher education research (vol. 4). Bingley: Emerald.

Pries, L. (Ed.). (2013). Shifting boundaries of belonging and new migration dynamics in Europe and China. Houndmills: Palgrave MacMillan.

Rosch, E. (1983). Prototype classification and logical classification: The two systems. In E. Scholnick (Ed.), New trends in cognitive representation: Challenges to Piaget's theory (pp. 73-86). Hillsdale: Lawrence Erlbaum.

Ryan, L. (2018). Differentiated embedding: Polish migrants in London negotiating belonging over time. Journal of Ethnic and Migration Studies, 44(2), 233-251.

Terkessidis, M. (2016). Das Programm Interkultur und die Aufgabe der Bildung. In E. Arslan \& K. Bozay (Eds.), Symbolische Ordnung und Bildungsungleichheit in der Migrationsgesellschaft (pp. 441-455). Wiesbaden: Springer VS.

van der Brug, W., D’Amato, G., Ruedin, D., \& Berkhout, J. (Eds.). (2015). The policitization of Migration. New York, NY: Routledge.

van der Werfhorst, H. G., \& Heath, A. (2018). Selectivity of migration and the educational disadvantages of second-generation immigrants in ten host societies. European Journal of Population. https://doi.org/ 10.1007/s10680-018-9484-2

Volante, L., Klinger, D., \& Bilgili, Ö. (Eds.). (2018). Immigrant student achievement and education policy. Cross-cultural approaches. Berlin: Springer.

Walters, W. (2016). Border/control. In A. Amelina, K. Horvath, \& B. Meeus (Eds.), An anthology of migration and social transformation. European perspectives (pp. 151-165). Berlin: Springer.

Wimmer, A. (2013). Ethnic boundary making, institutions, power, networks. Oxford: Oxford University Press.

Wischmann, A. (2018). The absence of 'race' in German discourses on Bildung. Rethinking Bildung with critical race theory. Race Ethnicity and Education, 21(4), 471-485.

Wotherspoon, T., \& Jungbluth, P. (1995). Multiculturalism and education in changing political economies. In T. Wotherspoon \& P. Jungbluth (Eds.), Multicultural education in a changing global economy. Canada and the Netherlands (pp. 1-22). Münster: Waxmann. 


\section{About the Author}

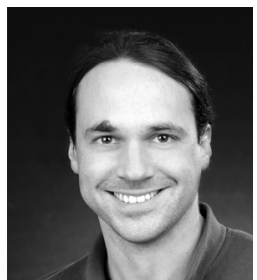

Kenneth Horvath is a Post-Doctoral Researcher at the University of Lucerne, Switzerland. He currently works on logics of classification and problematization in contexts of social inequalities, with a focus on the interplay of politics, education, and migration. His PhD research (conducted at the University of Vienna) investigated the interplay of securitization and economization of migration in the development of the Austrian migration regime 1945-2010. From 2012 to 2017, he held a post-doc position at the University of Education Karlsruhe, Germany. 